\title{
PENERAPAN MODEL REAL WORLD SITUATION PROBLEM BASED LEARNING MENGGUNAKAN KONTEKS ESD DALAM MENINGKATKAN SUSTAINABILITY AWARENESS SISWA DI KELAS X
}

\author{
Tiastuti Putria), Irma Rahma Suwarma ${ }^{\text {b) }}$, Agus Danawan ${ }^{\text {c) }}$, \\ Agus Fany Candra Wijayad) \\ Departemen Pendidikan Fisika Fakultas Pendidikan Matematika dan Ilmu Pengetahuan Alam Universitas \\ Pendidikan Indonesia. Jl. Dr. Setiabudhi No. 229, Bandung 40154, Indonesia \\ Email: a)tiastutiputri@gmail.com, b)
}

\begin{abstract}
Abstrak
Real World Situation Problem Based Learning adalah model pembelajaran yang melibatkan siswa untuk memecahkan suatu masalah yang ada di dunia nyata atau di dalam kehidupan sehari-hari yang dapat membangun pola berpikir kritis siswa. Education Sustainable Development (ESD) merupakan suatu konteks atau isu-isu ESD yang dijadikan suatu permasalahan terkait model pembelajaran yang digunakan untuk meningkatkan profil Sustainability Awareness siswa. Sehingga, Real World Situation Problem Based Learning dengan menggunakan konteks ESD dalam penelitian ini untuk meningkatkan profil Sustainability Awareness yang dimilikinya. Penelitian menggunakan metode penelitian deskriptif kualitatif. Instrumen yang digunakan adalah angket profil Sustainability Awareness dan wawancara. Instrumen diberikan kepada 30 siswa di salah satu SMA di Kota Cimahi. Hasil penelitian menunjukkan bahwa setelah kegiatan pembelajaran dengan menerapkan model Real World Situation Problem Based Learning Menggunakan Konteks ESD dapat meningkatkan profil Sustainability Awareness.
\end{abstract}

Kata-kata kunci: Problem Based Learning; Education Sustainable Development.

\begin{abstract}
Real World Situation Problem Based Learning is a learning model that engages students to solve a problem that exists in the real world or in daily life that can build a student's critical thinking pattern. Education Sustainable Development (ESD) is a context or ESD issue that is a problem related to the learning model that is used to improve students ' Sustainability Awareness profile. Thus, Real World Situation Problem Based Learning uses the ESD context in this study to enhance its Sustainability Awareness profile. Research uses qualitative descriptive research methods. The instrument used is a questionnaire of Sustainability Awareness profiles and interviews. The instrument was given to 30 students at one high school in Cimahi. The results showed that after learning activities by implementing the Real World Situation Problem Based Learning model using ESD context could improve the Sustainability Awareness profile.
\end{abstract}

Keywords: Problem Based Learning; Education Sustainable Development. 


\section{PENDAHULUAN}

Penduduk bumi saat ini dihadapkan pada permasalahan lingkungan yang krisis dalam berbagai aspek, seperti pemanasan global, perubahan iklim yang disebabkan oleh manusia, meluasnya gurun, menipisnya sumber daya alam (SDA), penyebaran frekuensi bencana alam, penyebaran penyakit menular, krisis atau hilangnya keanekaragaman hayati, gangguan pada lapisan ozon dan hutan hujan tropis, polusi air dan udara, serta masalah sosial seperti pelanggaran hak asasi manusia (HAM), meningkatnya masalah kemiskinan di negara berkembang, kelaparan, pertikaian antar agama dan etnis. Semua masalah itu membuat masyarakat tidak lagi mampu bertahan baik dalam lingkup lokal atau pun global dan salah satu diantaranya adalah kualitas pendidikan. Permasalahan yang dihadapi oleh satu negara akan berdampak pada sistem global, sehingga seringkali permasalahanpermasalahan di suatu negara perlu dibahas dan dipecahkan bersama-sama. Permasalahan politik, keamanan, ekonomi, sosial budaya dan lingkungan menjadi sebuah permasalahan yang sering dibahas dalam suatu konferensi global. Permasalahan kompleks di bumi ini perlu diselesaikan dengan pendidikan yang mengedepankan pentingnya lingkungan alam sebagai sumber hidup manusia. Hal tersebut didukung oleh Kementerian Pendidikan dan Kebudayaan dalam Rencana Strategis Tahun 2010-2014 bahwa: Pendidikan harus menumbuhkan pemahaman tentang pentingnya keberlanjutan dan keseimbangan ekosistem, yaitu pemahaman bahwa manusia adalah bagian dari ekosistem [1].

Kurikulum 2013 pada mata Nasional (2010-2014) tidak secara eksplisit menyatakan komitmen terhadap ESD, tetapi pada dasarnya pendidikan nasional Indonesia didedikasikan pada keseluruhan aspek pembangunan nasional, khususnya pengembangan SDM yang bersesuaian dengan tuntutan pembangunan dalam pelajaran fisika secara implisit sudah mengarah pada konsep pendidikan pembangunan berkelanjutan (PPB) atau education for sustainable development (ESD). Seperti adanya penerapan ilmu pengetahuan di dalam kehidupan sehari-hari yang berkaitan dengan isu-isu lingkungan, dengan adanya pembelajaran semacam itu diharapkan proses pembelajaran yang berlangsung di sekolah bisa menjadi lebih bermakna dan dapat mengarahkan siswa untuk berpikir ke depan serta memiliki kesadaran atas nilai-nilai berkelanjutan (sustainability awareness).

Berdasarkan hasil penelitian [2] di salah satu SMP Negeri di kota Sumedang didapatkan bahwa setelah diterapkannya model Problem Based Learning mengggunakan konteks ESD diperoleh nilai 0,71 , maka profil sustainability awareness termasuk ke dalam kategori tinggi. Problem based learning menjadi strategi pembelajaran yang sangat tepat untuk konteks ESD karena pada penelitian sebelumnya, diketahui problem based learning dapat meningkatkan output pembelajaran secara signifikan [3-5]. Dari penelitian tersebut terlihat bahwa setelah diterapkan model Problem Based Learning menggunakan konteks ESD maka profil sustainability awareness siswa meningkat. Sehingga dengan adanya hasil profil sustainability awareness di atas menunjukkan bahwa konsep ESD dapat digunakan dalam kegiatan pembelajaran.

Sehubungan dengan hal di atas, maka seorang guru mata pelajaran Fisika dalam Kurikulum 2013 dituntut untuk memilih dan menggunakan metode pembelajaran yang sesuai sehingga dapat meningkatkan nilai-nilai sustainability awareness siswa. Kurikulum 2013, siswa dibimbing untuk mengkonstruksi pengetahuan dibenak mereka sendiri sehingga dengan adanya hal tersebut anak belajar mengalami, mencatat sendiri pengetahuan baru yang didapatkan bukan diberi begitu saja oleh guru dan pengetahuan yang dimiliki seseorang itu mencerminkan pemahaman yang mendalam mengenai suatu persoalan (subject matter). Penjelasan tersebut sesuai dengan ESD yang mendukung lima macam dasar belajar untuk menyediakan pendidikan yang berkualitas dan membina manusia yang berkelanjutan yaitu learning to know, learning to be, learning to live together, learning to do dan learning to transform oneself and society [6].

Apabila proses pembelajaran siswa terbiasa dalam menghadapi permasalahan yang ada dalam kehidupan sehari-hari, memupuk rasa solidaritas sosial dengan terbiasa berdiskusi bersama temanteman, mengakrabkan hubungan antara guru dengan siswa maka akan didapatkan solusi untuk menyelesaikan permasalahan yang ada secara efisien dan selaras dengan konsep ESD. Untuk mendukung pembangunan berkelanjutan salah satunya ditunjukkan dengan sikap sustainability awareness. ESD akan melatih siswa untuk peduli terhadap lingkungan tanpa mengesampingkan 
kebutuhan di masa yang akan datang. Dengan menggunakan konteks ESD dalam model PBL diharapkan kesadaran atas nilai-nilai keberlanjutan (sustainability awareness) siswa meningkat.

Dengan melihat kecenderungan hasil penelitian sebelumnya solusi untuk permasalahan di atas salah satunya dengan menggunakan model pembelajaran berbasis masalah atau Problem Based Learning (PBL), dimana model pembelajaran tersebut sesuai dengan kurikulum 2013. Model pembelajaran PBL memiliki kelebihan yaitu siswa akan terbiasa menghadapi masalah dan tertantang untuk menyelesaikan masalah tidak hanya terkait dengan pembelajaran di kelas melainkan menghadapi masalah yang ada dalam kehidupan sehari-hari. Di dalam penelitian ini peneliti menambahkan kata Real World Situation dengan tujuan mendorong siswa untuk belajar melalui berbagai permasalahan nyata dalam kehidupan sehari-hari, atau permasalahan yang dikaitkan dengan pengetahuan yang telah atau akan dipelajarinya. Dan menggunakan konteks education for sustainable development (ESD) pada model pembelajaran berbasis masalah (PBL) diharapkan kesadaran siswa akan pentingnya lingkungan dapat meningkat serta memiliki kesadaran akan nilai-nilai keberlanjutan (sustainability awareness). Salah satu materi yang mungkin diterapkan dalam model PBL dengan menggunakan konteks ESD adalah materi Usaha dan Energi dengan isu ESD energi terbarukan (renewable energy), dimana energi khususnya energi listrik akan dapat menunjang kebutuhan dalam kehidupan sehari-hari. Maka dari itu, konsep dan profil sustainability awareness siswa SMA pada materi Usaha dan Energi dipandang perlu dilakukan.

\section{METODOLOGI}

Penelitian yang dilakukan menggunakan metode kualitatif dengan desain deskriptif kualitatif. Pada desain penelitian ini subjek penelitiannya adalah satu kelas. Di dalam desain penelitian ini, siswa diberikan perlakukan dan di akhir kegiatan pembelajaran setelah diberikan perlakuan sampel diberi angket untuk mengetahui profil sustainability awareness. Kemudian setelah mendapatkan hasil dari angket yang sudah dibagikan, peneliti memilih beberapa siswa untuk diwawancara. Desain ini sangat sesuai dengan tujuan penelitian yang dilakukan oleh peneliti yaitu mengetahui peningkatan profil sustainability awareness setelah diberi perlakuan berupa model pembelajaran Real World Situation Problem Based Learning (PBL) menggunakan konteks ESD.

Sampel dalam penelitian ini adalah sebanyak 30 orang siswa di kelas X IPA 3 SMA Negeri 1 Kota Cimahi. Instrumen yang digunakan dalam penelitian ini terdiri dari angket profil sustainability awareness dan wawancara. Instrumen angket profil sustainability awareness ini bertujuan untuk mengukur tingkat kesadaran siswa akan nilai-nilai keberlanjutan (sustainability awareness). Instrumen berupa angket ini terdiri atas 15 butir pernyataan dengan pilihan jawaban ya dan tidak yang diadopsi dari jurnal yang berjudul "The status on the level of environmental awareness in the concept of sustainable development amongst secondary school students". Tes ini diberikan setelah perlakuan (treatment) diberikan yang kemudian hasilnya dapat dianalisis untuk melihat profil sustainability awareness.

Data penelitian yang diperoleh kemudian dianalisis menggunakan skala Guttman. Skala Guttman merupakan salah satu skala pengukuran yang dapat digunakan dalam soal pilihan ganda, skala Guttman juga dapat digunakan dalam bentuk lembar checklist serta akan mendapatkan jawaban yang tegas seperti "benar-salah", "positif-negatif", "ya-tidak", dan lain-lain dengan data berupa data interval. Pada skala Guttman ini jawaban dapat dibuat skor tertinggi satu dan skor terendah nol, misalnya untuk jawaban siswa yang aware/ peduli diberi skor 1 dan jika sebaliknya diberi skor 0 . Kemudian data dibuat ke dalam bentuk persentase dengan cara sebagai berikut:

$$
\text { Persentase }(\%)=\frac{\text { Jumlah skor yang diperoleh }}{\text { Jumlah skor maksimum }} \times 100 \%
$$

setelah mendapatkan hasil dari skala Guttman untuk mengetahui profil Sustainability Awareness dikategorikan berdasarkan kriteria yang ada pada jurnal. Berikut ini kriteria sustainability awareness yang dikemukakan [7]: 
TABEL 1. Kriteria Sustainability Awareness

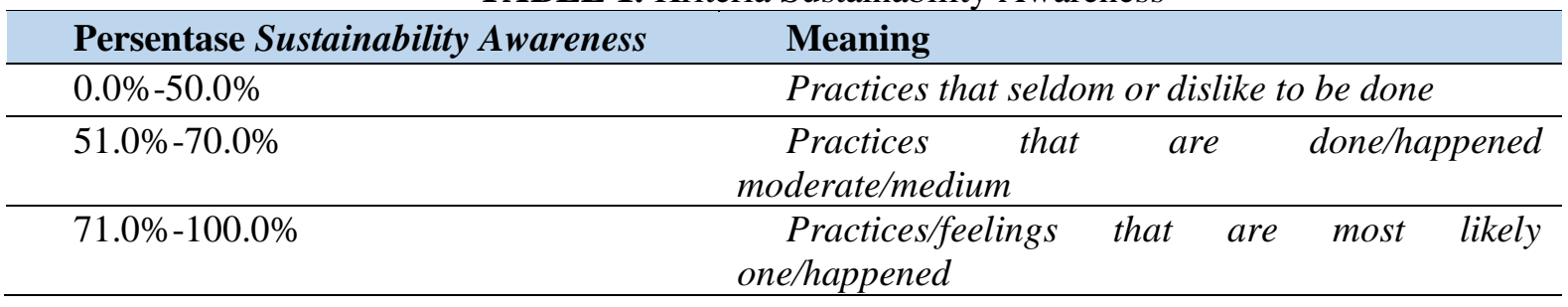

\section{HASIL DAN PEMBAHASAN}

\section{A. Hasil}

Untuk mengetahui profil Sustainability Awareness siswa setelah kegiatan pembelajaran dapat diukur dengan menggunakan angket Sustainability Awareness yang diadopsi dari jurnal yang berjudul "The status on the level of environmental awareness in the concept of sustainable development amongst secondary school students" berjumlah 15 butir pertanyaan untuk memprofilkan Sustainability Awareness siswa. Jumlah butir pernyataan pada angket tersebut dibagi menjadi tiga kategori yaitu sustainability practice awareness, behavioral and attitude awareness dan emotional awareness. Berdasarkan hasil temuan responden yang dalam ini merupakan siswa kelas X memiliki profil Sustainability Awareness dengan kategori Emotional Awareness. Berikut ini akan ditampilkan hasilnya dalam sebuah TABEL 2:

TABEL 2. Rekapitulasi Persentase Profil Sustainability Awareness

\begin{tabular}{|c|c|c|c|}
\hline No & Pernyataan & Mean & $\begin{array}{c}\text { Rerata } \\
\text { Persentase }\end{array}$ \\
\hline \multicolumn{4}{|c|}{ Sustainability practice awareness } \\
\hline 3 & $\begin{array}{l}\text { Saya selalu membahas masalah lingkungan dengan teman-teman } \\
\text { saya }\end{array}$ & 0,50 & $50 \%$ \\
\hline 9 & Saya mengomposkan sisa makanan menjadi pupuk & 0,13 & $13 \%$ \\
\hline 10 & Saya tidak menggunakan kantong plastik untuk membungkus barang & 0,13 & $13 \%$ \\
\hline 13 & $\begin{array}{l}\text { Saya menyampaikan informasi tentang lingkungan kepada anggota } \\
\text { keluarga saya }\end{array}$ & 0,60 & $60 \%$ \\
\hline 14 & Saya mengikuti dalam kegiatan penyadaran lingkungan di sekolah & 0,03 & $3 \%$ \\
\hline \multicolumn{4}{|c|}{ Behavioral and attitude awareness } \\
\hline 1 & Saya membaca tentang isu lingkungan di media massa & 0,77 & $77 \%$ \\
\hline 6 & Saya menghargai keanekaragaman hayati & 1,00 & $100 \%$ \\
\hline 7 & Saya peduli tentang asap yang berasal dari kendaraan-kendaraan & 0,87 & $87 \%$ \\
\hline 8 & $\begin{array}{l}\text { Saya mencoba mengurangi jumlah sampah di rumah dengan } \\
\text { mengumpulkan bahan yang bisa didaur ulang }\end{array}$ & 0,50 & $50 \%$ \\
\hline 11 & Saya tidak menghidupkam lampu di rumah pada siang hari & 0,93 & $93 \%$ \\
\hline 12 & Saya menghemat pemakaian air bersih & 0,87 & $87 \%$ \\
\hline \multicolumn{4}{|c|}{ Emotional awareness } \\
\hline 2 & Saya peduli dengan masalah lingkungan di tempat saya & 1,00 & $100 \%$ \\
\hline 4 & Saya merasa kecewa dengan polusi udara & 0,97 & $97 \%$ \\
\hline 5 & Saya merasa kecewa dengan polusi sungai & 1,00 & $100 \%$ \\
\hline 15 & Saya menyadari tanggung jawab saya terhadap lingkungan & 1,00 & $100 \%$ \\
\hline \multicolumn{2}{|r|}{ Mean Total } & 0,68 & $68 \%$ \\
\hline
\end{tabular}

Tabel diatas menunjukkan hasil mean total dari 15 pernyataan yang ada pada angket yaitu sebesar 0.68, sehingga dapat dikatakan bahwa profil Sustainability Awareness siswa kelas X 
termasuk kedalam kategori sedang. Sehingga rerata persentase profil sustainability awareness sebesar 68\%. Berikut ini tabel hasil profil sustainability awareness siswa secara keseluruhan: 
TABEL 3. Rekapitulasi Profil Sustainability Awareness Siswa

\begin{tabular}{cccc} 
No. & Nama Siswa & Skor & Nilai \\
\hline 1 & AS & 11 & 73,33 \\
\hline 2 & AM & 9 & 60,00 \\
\hline 3 & AF & 13 & 86,67 \\
\hline 4 & AP & 8 & 53,33 \\
\hline 5 & ANP & 10 & 66,67 \\
\hline 6 & ANF & 11 & 73,33 \\
\hline 7 & BA & 9 & 60,00 \\
\hline 8 & DF & 11 & 73,33 \\
\hline 9 & DMP & 13 & 86,67 \\
\hline 10 & ET & 10 & 66,67 \\
\hline 11 & FA & 10 & 66,67 \\
\hline 12 & HP & 12 & 80,00 \\
\hline 13 & KR & 10 & 66,67 \\
\hline 14 & LA & 8 & 53,33 \\
\hline 15 & LNH & 12 & 80,00 \\
\hline 16 & MAA & 9 & 60,00 \\
\hline
\end{tabular}

\begin{tabular}{cccc} 
No. & Nama Siswa & Skor & Nilai \\
\hline 17 & MRF & 11 & 73,33 \\
\hline 18 & NKH & 11 & 73,33 \\
\hline 19 & NS & 9 & 60,00 \\
\hline 20 & NDN & 12 & 80,00 \\
\hline 21 & NOVIA & 11 & 73,33 \\
\hline 22 & NF & 12 & 80,00 \\
\hline 23 & RAF & 11 & 73,33 \\
\hline 24 & RWP & 7 & 46,67 \\
\hline 25 & RR & 8 & 53,33 \\
\hline 26 & RF & 7 & 46,67 \\
\hline 27 & SA & 10 & 66,67 \\
\hline 28 & SH & 12 & 80,00 \\
\hline 29 & ZA & 11 & 73,33 \\
\hline 30 & ZSA & 10 & 66,67 \\
\hline \multicolumn{4}{c}{ Mtandar Deviasi } \\
\hline
\end{tabular}

Berdasarkan tabel diatas profil sustainability awareness siswa secara keseluruhan, setelah mengisi angket. Lalu skor yang didapatkan oleh siswa diubah ke dalam bentuk nilai sehingga didapatkan nilai mean sebesar 68.51, yang berarti profil Sustainability Awareness siswa kelas X termasuk kedalam kategori sedang dengan standar deviasi sebesar 10,74. Profil sustainability awareness terbagi ke dalam 3 kategori yaitu Sustainability practice awareness, Behavioral and attitude awareness dan Emotional awareness seperti yang ditunjukkan pada TABEL 4.

TABEL 4. Persentase Respon pada Setiap Kategori Sustainability Awareness

\begin{tabular}{ccc}
\hline $\begin{array}{c}\text { Kategori Sustainability } \\
\text { Awareness }\end{array}$ & $\begin{array}{c}\text { Respon "Ya" } \\
(\mathbf{\%})\end{array}$ & Keterangan \\
\hline $\begin{array}{c}\text { Sustainability practice } \\
\text { awareness }\end{array}$ & $28 \%$ & Masih jarang dilakukan \\
\hline $\begin{array}{c}\text { Behavioral and attitude } \\
\text { awareness }\end{array}$ & $81,67 \%$ & Sudah sering dilakukan \\
\hline Emotional awareness & $99,17 \%$ & Sudah sering dilakukan
\end{tabular}

Berdasarkan TABEL 4 untuk kategori yang pertama sustainability practice awareness terlihat bahwa persentase respon siswa untuk perilaku tersebut sebesar $28 \%$, yang artinya perilaku yang tertera dalam pernyataan pada angket masih jarang dilakukan. Sedangkan untuk kategori yang kedua behavioral and attitude awareness persentase respon siswa sebesar $81,67 \%$ yang berarti bahwa perilaku yang tertera dalam pernyataan pada angket sudah sering dilakukan. Begitupun untuk kategori yang ketiga yaitu emotional awareness sudah sering dilakukan sebab respon siswa yang didapatkan sebesar 99,17\%.

Untuk menguatkan hasil yang didapatkan dari angket penulis juga melakukan wawancara kepada 9 siswa. 2 siswa yang mendapatkan point tinggi pada saat mengisi angket, 4 siswa yang mendapatkan point sedang pada saat mengisi angket, dan 2 siswa yang mendapatkan point rendah pada saat mengisi angket. Wawancara dilakukan dengan memberikan tiga buah pertanyaan kepada siswa. Dan pada saat diberi pertanyaan hampir semua siswa menjawab dengan benar dan sesuai dengan konsep ESD. Sehingga dapat dikatakan bahwa siswa sebenernya dapat mendukung konsep ESD yaitu sikap Sustainability Awareness. Berikut ini merupakan hasil wawancara yang ditampilkan dalam bentuk TABEL 5: 
TABEL 5. Hasil wawancara terkait profil Sustainability Awareness

\begin{tabular}{|c|c|c|c|c|}
\hline No. & Pertanyaan & $\mathbf{N}$ & Ya & Tidak \\
\hline 1 & $\begin{array}{l}\text { Ketika sedang berada di suatu tempat } \\
\text { lalu ditempat itu tidak memiliki tempat } \\
\text { sampah, namun kalian mempunyai } \\
\text { sampah yang harus dibuang. Jika } \\
\text { disuruh memilih, kalian memilih untuk } \\
\text { meninggalkan sampah di tempat itu } \\
\text { atau membawa sampahnya? }\end{array}$ & 9 & 9 & - \\
\hline 2 & $\begin{array}{l}\text { Ketika di malam hari lampu akan } \\
\text { membantu penerangan di rumah kita, } \\
\text { jika disuruh memilih diantara dua } \\
\text { pilihan yaitu lampu LED atau lampu } \\
\text { biasa maka kalian akan memilih lampu } \\
\text { yang mana? Mengapa? }\end{array}$ & 9 & 6 & 3 \\
\hline 3 & $\begin{array}{l}\text { Listrik merupakan kebutuhan dalam } \\
\text { kehidupan manusia, namun listrik juga } \\
\text { bisa menjadi masalah dalam kehidupan } \\
\text { manusia, jika kalian disuruh memilih } \\
\text { menggunakan PLTU dengan tenaga } \\
\text { batu bara atau PLTA dengan tenaga } \\
\text { air? }\end{array}$ & 9 & 9 & - \\
\hline
\end{tabular}

Keterangan:

$\mathrm{n}=$ jumlah responden/ siswa yang menjawab pertanyaan dalam wawancara.

\section{B. Pembahasan}

Berdasarkan TABEL 4. Sustainability Awareness dikelompokkan kedalam 3 kategori. Untuk kategori yang pertama yaitu Sustainability practice awareness, yang termasuk kategori pertama adalah pernyataan nomor 3, 9, 10, 13 dan 14 dengan hasil yang didapatkan menunjukkan bahwa perilaku tersebut jarang dilakukan oleh sebagian besar jumlah siswa dengan presentase $72 \%$, sedangkan untuk siswa yang melakukan perilaku tersebut sebesar $28 \%$. Dengan adanya hal tersebut, dapat disimpulkan bahwa siswa tidak pernah melakukan perilaku Sustainability practice awareness. Sustainability practice awareness atau upaya sadar dan menjalankan keberlanjutan itu sangat jarang atau bahkan tidak pernah dilakukan oleh siswa seperti membahas isu lingkungan dengan teman, mengomposkan sisa makanan menjadi pupuk, tidak menggunakan kantong plastik untuk membungkus barang, membahas mengenai masalah lingkungan dengan keluarga dan juga mengikuti kegiatan penyadaran lingkungan di sekolah untuk mengatasi permasalahan lingkungan itu semua sangat jarang dilakukan oleh siswa berdasarkan angket yang mereka isi. Perilaku tersebut merupakan ciri dari sikap yang akan ditunjukkan apabila seseorang sudah mengerti tentang konsep keberlanjutan.

Kategori yang kedua yaitu Behavioral and attitude awareness atau perilaku dan sikap peduli terhadap lingkungan yang terdapat pada pernyataan nomor 1, 6, 7, 8, 11 dan 12, dari jumlah seluruh siswa dapat dikatakan bahwa $81,67 \%$ siswa melakukan perilaku tersebut dan $18,33 \%$ siswa tidak melakukan perilaku tersebut. Sehingga dapat disimpulkan bahwa perilaku dan sikap peduli terhadap lingkungan (Behavioral and attitude awareness) yang dimiliki siswa tinggi. Behavioral and attitude awareness atau perilaku dan sikap peduli terhadap lingkungan tidak dilakukan siswa seperti membaca isu lingkungan di media massa, menghargai keanekaragaman hayati, peduli terhadap asap kendaraan bermotor, mendaur ulang sampah rumah tangga, tidak menyalakan lampu disiang hari dan mengurangi pemakaian air bersih sering dilakukan atau yang paling mungkin terjadi di dalam kehidupan. Hal tersebut merupakan perilaku dan sikap yang ditunjukkan apabila seseorang peduli dan sadar akan pentingnya lingkungan. 
Kategori yang ketiga yaitu Emotional awareness atau kepedulian terhadap lingkungan secara emosi termasuk sikap atau perilaku yang selalu dilakukan oleh seluruh siswa terdapat pada pernyataan nomor 2, 4, 5 dan 15, terlihat pada tabel 3. presentase jumlah siswa yang bersikap Emotional awareness sebesar 99,17\%, secara emosional siswa memiliki kepedulian tinggi terhadap lingkungannya. Kepedulian terhadap lingkungan secara emosional seperti merasa peduli dengan permasalahan lingkungan, merasa kecewa dengan polusi yang ada di udara dan sungai serta sadar akan tanggung jawab manusia terhadap lingkungan itu dimiliki oleh siswa. Sehingga Sustainability awareness atau kepedulian berkelanjutan siswa berdasarkan kategorinya yang paling baik hanya peduli terhadap lingkungan secara emosional dan masih jarang kepeduliannya ditunjukkan dengan sikap apalagi secara keberlanjutan dilakukan terus menerus. Sehingga dapat disimpulkan bahwa berdasarkan 3 kategori Sustainability Awareness siswa hanya memiliki kesadaran terhadap nilai keberlanjutan pada tingkat emosi tanpa mempraktekannya dalam kehidupan sehari-hari ditunjukkan dengan nilai terbesar dengan prilaku tidak pernah melakukannya pada kategori Sustainability practice awareness.

Sikap Sustainability awareness dapat mendukung konsep pendidikan berkelanjutan atau ESD sehingga dengan hasil profil Sustainability awareness dengan kategori sedang dapat dikatakan bahwa sikap siswa yang diteliti sudah cukup untuk mendukung terhadap konsep ESD tersebut. Namun, hal tersebut belum sesuai dengan yang dikatakan oleh [4] bahwa yang dapat mendukung konsep ESD yaitu sikap Sustainability awareness yang tinggi.

Untuk menguatkan hasil penelitian peneliti melakukan wawancara kepada 9 siswa yang dipilih berdasarkan hasil angket profil sustainability awareness. Berdarkan tabel 4. pertanyaan wawancara yang pertama, pada saat penulis menanyakan kepada siswa ketika sedang berada di suatu tempat namun ditempat itu tidak ada tempat sampah dan kalian mempunyai sampah yang harus dibuang. Kemudian siswa diberikan dua pilihan untuk meninggalkan sampah di tempat itu atau membawa sampahnya. Pada pertanyaan pertama jika siswa menjawab membawa sampahnya maka siswa memiliki sikap Sustainability Awareness yang baik, begitupun sebaliknya. Dan pada pertanyaan pertama semua siswa memilih untuk membawa sampahnya dengan alasan agar lingkungan di sekitar tetap bersih dan nyaman.

Lalu pada pertanyaan wawancara yang kedua, saat penulis memberikan pertanyaan kepada siswa ketika di malam hari lampu akan membantu penerangan di rumah kita, lalu siswa disuruh memilih diantara dua pilihan jenis lampu yaitu lampu LED atau lampu biasa. Apabila siswa menjawab lampu LED maka siswa memiliki sikap Sustainability Awareness yang baik. Berdasarkan hasil wawancara yang didapatkan tiga dari sembilan siswa memilih lampu biasa dengan alasan karena tidak mengetahui apa itu lampu LED dan ada juga yang beralasan dengan lampu menggunakan lampu LED cahaya yang dihasilkan terlalu terang. Sedangkan 6 siswa lainnya menjawab lampu LED, dengan alasan lampu LED jauh lebih hemat energi dan membuat penerangan di rumah menjadi lebih terang. Sehingga dapat dikatakan bahwa siswa masih memiliki sikap Sustainability Awareness yang cukup baik.

Dan pertanyaan wawancara yang terakhir, pada saat siswa disuruh memilih solusi dari suatu permasalahan mengenai energi listrik, dimana pertanyaan tersebut adalah listrik merupakan kebutuhan dalam kehidupan manusia, namun listrik juga bisa menjadi masalah dalam kehidupan manusia, jika kalian disuruh memilih menggunakan PLTU dengan tenaga batu bara atau PLTA dengan tenaga air. Semua siswa memilih PLTA dengan tenaga air, dengan alasan PLTA lebih ramah lingkungan dan air akan terus-menerus ada atau bukan merupakan sumber daya alam yang tidak dapat diperbaharui. Sehingga dapat dikatakan bahwa siswa memiliki sikap Sustainability Awareness yang baik.

Oleh karena itu, dari ketiga pertanyaan yang diajukan kepada penulis dapat dikatakan bahwa sikap Sustainability Awareness yang dimiliki baik. Dan sesuai dengan yang dikatakan oleh Hasan bahwa yang dapat mendukung konsep ESD yaitu sikap Sustainability awareness yang tinggi. Sehingga, sikap Sustainability awareness siswa dapat mendukung konsep pendidikan berkelanjutan atau ESD meskipun dengan hasil profil Sustainability awareness pada kategori sedang [4]. 


\section{SIMPULAN}

.. Berdasarkan pengolahan dan analisis terhadap data hasil penelitian yang telah peneliti dapatkan di lapangan, maka dapat disimpulkan yang dapat menjawab pertanyaan dalam penelitian ini, yaitu terdapat peningkatan profil sustainability awareness siswa. Pada pokok bahasan usaha dan energi subbab energi dengan isu ESD yaitu energi terbarukan setelah diimplementasikan dalam pembelajaran fisika menggunakan model Real World Situation Problem Based Learning menggunakan konteks ESD dengan interpretasi skala Guttman menunjukkan peningkatan termasuk kategori sedang. Dengan hasil profil Sustainability Awareness siswa yang terbagi menjadi 3 kategori yaitu Sustainability practice awareness dengan presentase sebesar $28 \%$ sangat jarang dilakukan, Behavioral and attitude awareness presentase $81,67 \%$ sering dilakukan dan Emotional awareness dengan presentase $99,1 \%$ hampir selalu dilakukan oleh siswa. Sehingga dapat disimpulkan bahwa berdasarkan 3 kategori Sustainability Awareness siswa hanya memiliki kesadaran terhadap nilai keberlanjutan pada tingkat emosi tanpa mempraktekannya dalam kehidupan sehari-hari ditunjukkan dengan nilai terbesar dengan prilaku tidak pernah melakukannya pada kategori Sustainability practice awareness.

Dan untuk menunjang serta memperkuat hasil dari penelitian ini, peneliti melakukan wawancara kepada 9 orang siswa yang dipilih berdasarkan hasil angkat profil sustainability Awareness. Berdasarkan hasil wawancara dari ketiga pertanyaan yang diajukan kepada penulis dapat dikatakan bahwa sikap Sustainability Awareness yang dimiliki baik. Dan sesuai dengan yang dikatakan oleh [4] bahwa yang dapat mendukung konsep ESD yaitu sikap Sustainability awareness yang tinggi. Sehingga, sikap Sustainability awareness siswa dapat mendukung konsep pendidikan berkelanjutan atau ESD meskipun dengan hasil profil Sustainability awareness pada kategori sedang.

\section{REFERENSI}

[1] Kementrian Pendidikan Nasional "Model Pendidikan untuk Pembangunan Berkelanjutan (Education for Sustainable Development/ ESD) melalui Kegiatan Intrakulikuler", Pusat Penelitian Kebijakan, Balitbang Kemdiknas, Jakarta, 2010.

[2] L. Iif, "Integrasi ESD (Education Sustainable Development) dalam Pembelajaran IPA untuk Meningkatkan Prestasi Belajar dan Profil Sustainability Awareness Siswa SMP pada Topik Perubahan Iklim," skripsi, Departemen Pendidikan Fisika, Universitas Pendidikan Indonesia, Indonesia, 2018.

[3] A. P. Sari, S. Feranie, and S. Karim, "Penerapan Pembelajaran Berbasis Masalah dengan Pendekatan Multirepresentasi untuk Meningkatkan Prestasi Belajar dan Konsistensi Ilmiah Berbasis Multirepresentasi pada Materi Elastisitas", jpppf, vol. 1, no. 2, pp. 45 - 50, Dec. 2015.

[4] M. G. Nugraha, K. H. Kirana, S. Utari, N. Kurniasih, N. Nurdini, and F. N. Sholihat, "Problem Solving-Based Experiment untuk Meningkatkan Keterampilan Penalaran Ilmiah Mahasiswa Fisika”, jpppf, vol. 3, no. 2, pp. 137 - 144, Dec. 2017.

[5] A. Malik, "Model Pembelajaran Problem Based Instruction untuk Meningkatkan Penguasaan Konsep dan Keterampilan Proses Sains Mahasiswa", jpppf, vol. 1, no. 1, pp. 9 - 16, Jun. 2015.

[6] UNESCO. (2009). Review of Contexts and Structures for Education for Sustainable Development [Online]. Avaible: http://www.unesco.org/education/justpublished desd2009.pdf. [Accessed 18 March 2019].

[7] Hasan, A. Ariffin, T. Sulaiman, S, "The status on the level of environmental awareness in the concept of sustainable development amongst secondary school students", Procedia Social and Behavioral Sciences 2 (2010) 1276 - 1280, 2010. 
